\title{
Increasing Economic Interdependence between China and ASEAN and Its Implications ${ }^{1}$
}

Wai Ting
Hong Kong Baptist University, Hong Kong

\begin{abstract}
This paper aims to study the problems and issues of China's relations with ASEAN, which has achieved the establishment of ASEAN Economic Community by 2015. Taking into consideration the institutional framework constituted by the multiple agreements signed between China and ASEAN, how will the development of China-ASEAN relations be influenced by increasing economic interdependence between the two? What will be the difficulties ahead in enhancing trade and investments? Does promoting economic cooperation lead to more mutual trust in the political-strategic arena? China's recent policy in developing "One Belt, One Road," and Chinese relations with the U.S.-led Trans-Pacific Partnership and their implications to ASEAN will also be examined in this paper.

Key words: ASEAN Economic Community, asymmetric interdependence, One Belt One Road, Trans-Pacific Partnership, Regional Comprehensive Economic Partnership, New Security Outlook, Intellectual Property Rights, regional public goods
\end{abstract}

\footnotetext{
${ }^{1}$ This is a revised version of a paper originally presented to the International Seminar on Strengthening ASEAN Economic Community Resilience in Facing the Global Economic Crises at the National Resilience Institute of Republic of Indonesia (Lemhannas RI) in Jakarta, 18 November 2015. 


\section{Introduction}

The establishment of ASEAN Economic Community (AEC) by 2015, as decided by ASEAN leaders in 2007, was expected to pave the way for a more indepth integration of the economies of the ten member states. This paper aims to study the prospects of AEC in the context of China-ASEAN relations. Not only the Chinese perspective regarding the AEC will be studied, but also the problems and issues of China's relations with ASEAN will be examined. The downturn of global economy, the economic slowdown of China that used to be one of the motors that drove the whole world, the difficult recovery of the developed world, and the sudden loss of momentum of Brazil, Russia, India, China, and South Africa (BRICS) in becoming another engine for boosting the world economy are all major problems that contribute to the global recession. They pose significant impact to the future of AEC. China's economy is in slowdown, and Xi Jinping has asked for a minimum annual growth rate of 6.5 per cent until 2020. Although in such circumstances China could still offer opportunities to Southeast Asian countries, one should not underestimate the challenges and problems that ASEAN has to face resulting from China's economic downturn.

The political and economic relations between ASEAN and China have been circumscribed by a series of treaties and agreements that constitute the institutional framework within which their future relations develop. ASEAN in the past always wanted to construct multilateral frameworks in managing the relations with its northern powerful neighbor, so that the margin of maneuver of China could be restrained. This is what a scholar called ASEAN's 'omni- enmeshment' strategy towards China and other major powers (Goh, 2007-08, pp. 113-157). Before the mid-90s, Beijing refused to be 'bounded' by the international norms or the rules of the games internalized by these multilateral frameworks, so they chose not to join them. Beijing did not wish to be 'locked' by those multinational frameworks. However, after the end of Cold War, China aspired to 'join the world' and integrated into the global capitalist system. Since the mid-1990s, China changed its policies from refusing to join those multilateral frameworks to actively participate in them. The pragmatic Chinese leaders have then realized that from a realist perspective China could try to maximize its influence within the multilateral institutions. Moreover, if Beijing is not satisfied with the frameworks or international institutions, it could only seek transformation from within after it becomes a participating member. From a liberalist-institutionalist perspective, China could forge ahead the development of these international institutions basing on the spirit of consensus and cooperation, thus demonstrating its goodwill.

In this spirit, China joined the ASEAN Regional Forum (ARF) as a dialogue partner in 1994. The series of multilateral institutional frameworks that China participates in include the Declaration of Conduct of Parties in the South China Sea signed in 2002; the Framework Agreement on Comprehensive Economic Cooperation signed in November 2002 for the establishment of Free-Trade Area (FTA) by 2010, followed by the Protocol to Amend the Framework Agreement 2003 signed in Bali; the Treaty of Amity and Cooperation in Southeast Asia signed in October 2003; the framework agreement 
on ASEAN-China FTA (ACFTA) that came into force in July 2005; the Trade in Goods Agreement signed in November 2004; the Trade in Services Agreement signed in January 2007; the Investment Agreement signed in August 2007; and the Second Agreement of Trade in Goods within the Framework Agreement on Comprehensive Economic Cooperation signed on 29 October 2010.

Additionally, there are some new institutional agreements in the pipeline, including the Code of Conduct of Parties in the South China Sea, which is now under discussion; the Action Plan to Implement the Declaration on ChinaASEAN Strategic Partnership for Peace and Prosperity (2016-2020); the China ASEAN Treaty on Good Neighborliness, Amity and Cooperation; and the Treaty on Southeast Asian Nuclear Weapon Free Zone.

The Chinese principles in dealing with its relationship with ASEAN can be summarized by the followings: good neighborliness, mutual trusts, as well as bringing harmony, security and prosperity to neighbors, as proposed by the former Premier Wen Jiabao, and the 'New Security Outlook.' Taking into consideration the institutional framework constituted by these multiple agreements and the principles of Chinese diplomacy, how do we see the development of ASEAN when the extent of interdependence between China and ASEAN has been enlarged in the past years? Does enhancing economic cooperation lead to more mutual trust in the political-strategic arena? Are the numerous institutional frameworks conducive to a more institutionalized relationship between China and ASEAN? We refer to the concept of complex interdependence by Keohane and Nye, which is conducive to a better understanding among nation-states due to their increasing interactions in the economic and trade areas as well in social and cultural exchanges. According to the two authors, interdependence means mutual dependence (Keohane and Nye, 2001, p. 7). Although both actors have to measure their benefits against the costs incurred during the interactions, asymmetry in dependence between the two entities is inevitable. Asymmetrical interdependence can become a source of power for the less dependent actor (Keohane and Nye, 2001, pp. 5-17). The issue of asymmetrical interdependence between ASEAN and China has become a serious concern of all ten ASEAN members. It is the aim of this paper to study whether the Chinese government's perspectives and its policies regarding ASEAN have taken into consideration this phenomenon of complex interdependence.

This paper will not elaborate on the political aspect of China-ASEAN relations, which has long been overshadowed by the South China Sea problem. Beijing seems to separate politics from economics, hoping that yangli (yielding benefits) to others would alleviate political discordance.

\section{ASEAN-China Trading Relationship: Changing Pattern}

In the AEC Blueprint issued in 2007, it is stipulated that by 2015 when AEC is established, the construction of a single market and production base will be accomplished. There should be free flow of goods, services, investments, capital, and skilled labor (ASEAN Economic Community Blueprint, 2007). It seems that the idea and implementation of a regional economic community demonstrate a key point raised by researchers regarding the 
implications of globalization. Current researches have shown that regionalization has been enhanced as a result of globalization. Intra-regional trade, investments, and labor flow in various regions are further promoted as a result of economic globalization. China as a neighboring great power in phenomenal growth definitely plays a role in the further regionalization of the Asia-Pacific region, by linking East and Southeast Asia. What kinds of economic and political implications would be effectuated especially after the ACFTA has come into force?

Premier Li Keqiang proposed the upgrade of ACFTA during the tenth China-ASEAN Expo and the ChinaASEAN Business and Investment Summit in 2013,

“... on further lowering tariff rates, cutting non-tariff-related measures, launching dialogues for a new round of service trade pledge, and pushing forward the actual opening-up for investment through policies concerning access and personnel travels, so as to boost the liberalization and facilitation of trade and investment."(Li Keqiang, 2013)

In October 2013, during the ASEAN-China Summit, Li proposed a ' $2+7$ cooperation framework,' which includes a two-point political consensus on good neighborliness and mutual trust, as well as deepening cooperation for mutual benefits. For the seven point proposal, it includes:

1. discussing the signing of the treaty of good neighborliness and friendly cooperation,

2. creating an upgraded version of the ACFTA,

3. boosting mutual connectivity infrastructure and establishing the
Asian Infrastructure Investment Bank (AIIB),

4. boosting financial cooperation,

5. carrying out maritime cooperation,

6. strengthening exchanges in the security field, and

7. promoting people-to-people and cultural exchanges (ASEAN-China Center).

Chinese scholars consistently indicate that China always tries to "give more than take" so as to benefit the developing countries especially its Asian neighbors. A Beijing professor stresses that,

“The principle of 'give and take' on equal footing defines most of the FTA negotiations. However, to show its generous spirit to its neighboring countries, especially the less developed countries, China adheres to the strategic principle of 'giving more while taking less,' or at times only 'giving without any taking,' and equality and mutual benefit all the time." (Ying Fan, 2012, p. 109)

As a result of this 'principle,' China continued to have trade deficits with ASEAN countries, importing more than exporting, for a relatively long period in the past in 2000-2011 (Jiang and Cai, 2013, p. 16). During this period, exports from ASEAN to China have increased much more than the imports from China to ASEAN countries (Hatakeyama, 2012, p. 105). However, during the period of 2012-2014, the growth rate of China's imports from ASEAN increased only nominally, from 24.7 per cent in 2011 to only 1.6 per cent in 2012, 1.8 per cent in 2013, and 4.4 per cent in 2014. But China's exports to ASEAN increased in a significant way, from 23.1 per cent in 2011, to 20.1 per cent in 2012, 19.5 per cent in 2013 , and 11.3 per cent in 
2014. ${ }^{2}$ In 2011, the exports of China to ASEAN was valued at US $\$ 170$ billion, but only three years later, in 2014, the value of total exports increased to US $\$ 271.7$ billion. On the contrary, in 2011 the imports of China from ASEAN were valued at US $\$ 192.8$ billion, but thereafter the value of imports remained stagnant and reached only US\$208.1 billion in 2014 .

So, starting from 2012, ASEAN suffers from having trade deficits with China. In 2012, the deficit was US $\$ 8.5$ billion, but this increased to US $\$ 44.7$ billion in 2013, according to the statistics of Chinese Ministry of Commerce (Salidjanova et al., 2015, p. 5). The trade deficit was further increased to $\$ 63.6$ billion in 2014 (ASEAN External Trade Statistics 2014 and Direction of Trade Statistics, IMF, 2015). Is this a result of ACFTA, which largely facilitates the exports of China, especially its mechanical, electrical, and manufactured products?

The party-state in China still plays a prominent role in guiding and monitoring its national economy. The downturn of Chinese economy since 2014 to a certain extent is related to the diminishing market demand in Europe and the United States (U.S.), which results in the significant reduction of Chinese exports to the developed world. With the encouragement and assistance provided by the state, Chinese enterprises have strenuously searched for the expansion of external markets for their products.

ASEAN has been in moderate and steady growth, attaining an average annual GDP growth of 5.5 per cent recently. This is considered to be a steadily expanding market especially for

\footnotetext{
${ }^{2}$ Author's own calculations based on the statistics of Chinese Ministry of Commerce.
}

the industrial goods. It is obvious that China continues to expand its exports of machinery and manufactured goods to ASEAN, benefitting from the coming into force of ACFTA which has reduced the tariff to zero for 93 per cent of all the products from ASEAN by 1 January 2010. However, it should be noted that a large number of sensitive products is not included in the list of zero tariff. So, in the 'upgraded' version of ACFTA, the number of sensitive and highly sensitive products should be reduced (Wei Min, 2015, p. 130).

On the other hand, has China significantly reduced the import of raw materials, minerals, fuels, and even agricultural products on which ASEAN countries largely depend as exports? As the prices of these products are relatively low in comparison to industrial products, even if there might be growth in exports, the total value cannot be significantly enlarged. What is worse is that the prices of these primary materials are still suffering from downward trend. According to the agreement on trade in goods, the tariff-reduced products are divided into three categories: normal, sensitive, and highly sensitive products. The highly sensitive ones, including rice, sugar, plant oil, automobiles, and certain petro-chemical products, are still under tariff protection until 2015. We have to wait and see whether abolishing all the tariffs and non-tariff barriers to those products would boost up the two-way trade, or benefit more to one counterpart or another.

ASEAN should enhance its competitiveness in such traditional products such as food, fisheries, agricultural, and forestry commodities. ASEAN and China used to be competitors in exporting to third countries, as their 
exports of manufactured goods are quite similar. They are also competitors in attracting investments. But it seems that at least in the production chain they could be complementary to each other, as enterprises in China are looking to export their labor-intensive manufacturing industries to Southeast Asia, giving the increasingly high cost of labor in China.

Apart from the structural problems in trade as mentioned above, a Chinese scholar highlights several major insufficiencies of ACFTA. First, the favorable policy has not been fully utilized by the enterprises, as some of the measures to facilitate trading are not yet applicable and the transaction costs are still high. Second, the degree of openness of trade in services is relatively low. The openness of sectors like intellectual property rights (IPR), government procurement, technological, and environmental problems has not yet been treated. Third, there are still severe legal restrictions to financial services and economic connectivity, which hamper the conditions for economic development (Wei Min, 2015, 130). It is obvious that ASEAN countries have serious concerns regarding the opening up of the market of these significant sectors. However, opening up the service sectors and financial sector, as well as giving emphasis on IPR and environment concern, are key issues that should be considered in the development of the next stage of the FTA.

\section{Investments Opportunities in ASEAN}

From 2012 to 2014, the total Foreign Direct Investments (FDI) in ASEAN reached US $\$ 369$ billion, out of which China's amounted only to $\$ 21.4$ billion, after the European Union (EU), Japan, and the U.S., and not much different from the value of Hong Kong's investments (US\$20.2 billion) (Zhang, 2015, p. 28, and Statistics of ASEAN, 2015). However, investments on electricity and exploration of raw materials constitute 31.7 per cent of the total China's investments, and investments in manufacturing industries only reach 13.4 per cent. The Chinese invest significantly in infrastructure, real estate, financial services, and service industries. ASEAN and China industrial structures are quite similar and at the same time competitive, as they continue to produce for the enterprises of the developed world.

Recently, some Chinese analysts try to promote further interdependence of economic relations between ASEAN and China through constructing an internationalized production network, or the so-called 'vertical specialization.' China aspires to become the source of technological invention, center of innovation, and research and development. If the Chinese enterprises succeed in designing their own brands and designs, they can establish their own system of division of labor in the regional value chain through manufacturing the products in the neighboring developing countries. That is to say, the laborintensive production process is transferred to ASEAN countries. The vertical specialization thus produced creates a 'win-win' situation in regional cooperation, and the products can be sold first in China, ASEAN, and other developing countries with similar demand. This first step is considered to be important, because if the newly developed industrial powers rely significantly on overseas market, this will certainly arouse fierce competition from the more established industrial powers. It is only at the later stage that the Chinese-designed successful products can enter the market of developed world through linkages to 
the multinational companies and international buyers. It is only at that time that the Chinese enterprises are able to establish their own system of division of labor in the global production and value chain.

On its road to become a global economic power, China is aspiring to be not only the major supplier of final products to the vast Chinese and ASEAN markets, but also the center of innovation and design of new industrial products. In order to achieve this objective, China needs to largely improve its ability to innovate. China can also assist other Asian neighbors to be less reliant on European and U.S. markets, as the vast Chinese market is growing, and the manufacture process in Southeast Asian countries of Chinese-designed goods helps to promote their economic development. All these are instrumental in stabilizing and forging ahead the further development of East Asian regional economy. Constructing a vertical specialization is thus considered to be the foundation for China to become both the innovator and the recipient of final products. If China can design and the vast Chinese market can absorb these newly designed products with the production process shifting to ASEAN, it is considered as part of the upgraded version of ACFTA (Zhang, 2015, p. 31).

ASEAN countries benefit from the moving of labor intensive industries from China to ASEAN countries. In summer 2015, there was a remarkable decrease of foreign currencies reserve in China, from \$3.99 trillion in June 2014 to \$3.21trillion in June 2016 (figures from Trading Economics). This is due to a decrease in renminbi (RMB) savings in exchange for foreign currencies and relocation of investments from Mainland China to Southeast Asia and other parts of Asia by a large number of enterprises from Taiwan, Hong Kong, and other countries. The labor-intensive manufacturers in Southern China have been facing increase in wages and shortage of labor workers. Many factories have been obliged to move to Southeast Asian countries like Cambodia, Vietnam, Laos, and Indonesia, and even India. China used to be the major recipient of these investments, which have their production process in the coastal areas of China. So, China was the competitor of ASEAN countries for those export-oriented investments in the past. Now, with the facility provided by investment promotion, shifting the production to ASEAN will help to sustain the development in ASEAN and increase employment.

ASEAN can benefit from the affluent middle class that has been growing significantly in China. It is expected that the middle class will "change consumer lifestyles, thus stimulating imports of quality and luxury products and services from ASEAN countries" (Chinvanno, 2015, p. 13). However, the slowdown of Chinese economy since 2014 has started to pose a real challenge for ASEAN exports. ASEAN countries should be aware of a protracted slowdown in the Chinese economy that results in a reduction of imports from ASEAN. As a result, Southeast Asian countries aim to increase domestic demand as well as productivity. Intra-ASEAN trade has increased to 24.1 per cent of ASEAN's total trade in 2014 (ASEAN External Trade Statistics, 2014) and this should be further promoted in the new ten-year strategic plan aiming for deeper integration beyond 2015.

Since the signing of the agreement on trade in services, the financial, tourism, information technology, education, and 
logistics sectors have benefitted. However, even Chinese scholars stress that the Chinese investments should not focus on speculative profit-making activities like real estate development. They should learn from the Japanese experience in investing in public transport, education, and technology skill training in order to assist the host country in establishing a solid foundation for further development. China and ASEAN should cooperate to produce the so-called 'regional public goods' catering for the needs of ASEAN countries. This is considered as crucial in order to 'earn the trust, improve China's image and appeasing effects" among the neighboring countries. This demands not only financial and technical aid from Beijing, but the latter should be more thoughtful in offering assistance in education, medicine, and social security (Wang and Zhang, 2015, p. 31).

China has set up a "US\$15 billion credit facility and a US\$10 billion ChinaASEAN Investment Cooperation Fund with a focus on infrastructure and connectivity, thus helping to realize the ASEAN community by 2015" (Soerakoesoemah, 2012, p. 19). China is raising US $\$ 3$ billion for the second stage of China-ASEAN Investment Cooperation Fund, but so far the usefulness of this fund has not been very clear (Wei Min, 2015, p. 139).

\section{China's Grand Strategy of ‘One Belt, One Road'}

During the visit of $\mathrm{Xi}$ Jinping to Kazakhstan in September 2013, he proposed the idea of jointly constructing the 'Silk Road Economic Belt.' Two months later when he visited Indonesia in November 2013, he proposed the idea and policy of constructing the 'Maritime Silk Road.' Many scholars in China are actively engaging in justifying the necessity of this policy, searching for the essence of its meaning, and finding ways to implement it, whereas scholars outside China want to examine the geopolitical and geo-economic reasons behind the launching this policy and its implications.

China has already committed US $\$ 100$ billion in October 2014 for the AIIB and contributed US $\$ 40$ billion in November 2014 for the 'Silk Road Fund.' Beijing also committed to establish the 'New Development Bank' with the BRICS. The Greater Mekong Sub-region is considered to be the first testing ground for the so-called economic integrative development. All these banks serve to finance those projects of infrastructural development, including railway, highway, sea transportation, aviation, electricity, water, as well as real estates, so as to facilitate the exchanges of personnel, trade, capital, technology, and agricultural products. China has already started the extension of its electricity grid to Southeast Asian countries, through the socalled 'ASEAN Inter-connected Power Grid' (Report on the Transfer of Electricity from Southern China to ASEAN Countries). Now, the China Southern Power Grid company has already supplied electricity to Laos, Myanmar, and Vietnam. ${ }^{3}$ This is in reality a result of the over-capacity in the production of electricity in China, as well as the slow growth or even reduction of electricity consumption in various provinces as a result of the Chinese economic downturn since 2014.

There are two economic factors that play a part in the formulation of this

\footnotetext{
${ }^{3}$ China has two electricity grids: the National Power Grid and the Southern Power Grid. The latter supplies electricity to five provinces: Guangdong, Guangxi, Yunnan, Guizhou, and Hainan.
} 
policy. First, the abundant foreign currency reserves of China, which amounted to a maximum of $\$ 3.99$ trillion in June 2014 but dropped to $\$ 3.21$ trillion in June 2016 due to the outflow of foreign capital, has always been a problem for the financial situation of China. In the past, it was constantly a source of pressure for the appreciation of RMB. Now, Beijing is suffering from the pressure for depreciation. How to make the best use of the foreign currencies is a difficult issue, as investments in wealthy developed world like Europe and the U.S. are usually risky. So, buying U.S. bonds is the ultimate outcome, but lending money to the U.S. will curtail losses to China if the U.S. dollar is devalued. By the 'One Belt, One Road' policy, China can lend money through the AIIB or Silk Road Fund to Southeast Asian states, which will then make use of the loan to improve their infrastructural development.

Second, any infrastructural development will make use of cement, iron and steel, aluminium, chemicals, and heavy machinery. All these sectors in China are in a state of over-capacity. The prices of all these minerals and commodities have dropped significantly. The numerous factories that are set idle desperately need new markets as the Chinese market is over-saturated. For every city of China, whether big or small, there must be several or over a dozen newly developed regions outside the cities. All these so-called 'ghost cities' are able to house millions of people, as proclaimed by an expert on urban development in a recent conference held in Beijing. Now, China wants to help the neighboring developing countries to build infrastructure. They obtain the loan from China then make use of the loan to buy Chinese materials, expertise, and technology, that is to say, to keep the
Chinese factories that produce steel, cement, and even locomotive working.

However, we need to consider whether these developing countries are able to pay back the capital investments that they borrow from China. The capital investment of billions of US dollars in building a railway depends on the loan, but is the country able to generate enough profits from the operation of the railway so that it could pay back the loan? This is a legitimate question that Chinese decision-makers must clarify. If some countries are not able to pay within the designated period, will China exempt their debts, as it has done in the past in dissolving the debts of the poorest African countries?

One recent example can be demonstrated by the Laotian railway built by China. The two countries signed an agreement in 2015 in Beijing on the construction and operation of a $418 \mathrm{~km}$ railway in Laos. The total investment is RMB40 billion yuan. The proportion of China's share is 70 per cent while Laos' is 30 per cent, which means Laos has to contribute RMB12 billion yuan (Ming Pao, 2015 , p. A23). Since the railway will link up China's domestic railway network with Thailand's and Malaysia's in the future, it can be regarded as a 'political project,' whereas the profitability of the railways seems to be doubtful but it is of secondary importance.

If China is able to construct the high-speed railways ${ }^{4}$ that connect China

\footnotetext{
${ }^{4}$ It should be specified that the relatively highspeed trains that run for $200 \mathrm{~km}$ per hour are called 'dongche' (dynamic trains) in Chinese, while those extra high-speed trains that run for more than $350 \mathrm{~km}$ per hour are called 'gaotie' (high-speed trains). The former can use the ordinary conventional railway, while the
} 
to Europe via the numerous countries in Central Asia, Western Asia, and Eastern Europe, the whole railway system together with the communication, signal, and software system designed by China will be utilized by all the countries concerned. This is a significant achievement of China that brings remarkable political and economic implications. During the past 36 years of reform and open door period, China eyes on Western assistance in providing capital, expertise, and technology. Now, geopolitically speaking, China pays attention to the countries in its south and west and endeavors to modify the landscape of those countries through China's economic power.

\section{The RCEP and China's Reactions to the U.S.-Dominated Trans-Pacific Partnership}

Apart from its grand initiative of One Belt, One Road, Beijing seems to be eager to play a leading role in the ASEAN initiative of Regional Comprehensive Economic Partnership (RCEP), which was launched in 2012, that brings together the ten ASEAN members states with the six states that have free trade agreements with ASEAN, including China, Japan, India, South Korea, Australia, and New Zealand. Fifteen rounds of negotiation have covered areas in trading in goods and services, investment, IPR, economic and technical cooperation, dispute resolution, and legal issues. Key concerns include lowering tariffs especially in agricultural sector, an important issue for Japan that is concerned with opening its

latter are much more demanding technologically, requiring an isolated and specially constructed railway. However, in the Chinese publicities regarding the exportation of train technology, the word 'gaotie' is always used. agricultural market. Another concern is to push ahead investment opportunities that stronger powers such as Japan and China are enthusiastic to achieve. The RCEP is considered as another grand design for China in orchestrating the establishment of an upgraded FTA in the Asia-Pacific region, in competition to the Trans-Pacific Partnership (TPP) led by Washington. Since the new U.S. President Donald Trump has already mentioned his will to dismantle the TPP before his advent to power given his protectionist stance, Asian countries including even Japan are looking at RCEP in considering their future in the regional cooperation efforts.

The original proposal of four small states - Singapore, Brunei, New Zealand, and Chile - which largely rely on trade for their economic development, was baptized in 2005 as the 'Trans-Pacific Strategic and Economic Partnership.' They aimed to promote free trade 'at a higher level.' They wished to draw attention to the necessity of 'upgrading' free trade. However, facing the difficulties in negotiations within World Trade Organization (WTO) and the predominance of great powers, what they could do was rather limited. When the U.S. took over the proposal after the advent of President Barack Obama to power and changed its name to TPP in 2009, Washington sought the approval of other countries in creating a 'new' FTA that has to take into consideration some new conditions in relation to IPR, labor rights, transparency in decision-making, finance, e-commerce, private property, and environmental protection and conservation. Even for the traditional areas like commodity trade and trade in services, the TPP set a higher standard. Zero tariff will be enforced for all products, and for the market access in services trade, the TPP is very liberal, 
allowing the 'pre-establishment national treatment,' plus most-favored-nation and exception clause (Wu and Qu, 2014, p. 67).

The TPP agreement, signed on 5 October 2015, marked a significant victory of the U.S. in determining the 'rules of the games' in international trade in the future. The TPP can be considered as the creation of new norms and regulations in international trade, led by the largest economy (the U.S.) and the third largest economy (Japan) for the further development of regional economy (Ta Kung Pao, 2015, p. A24). The 'high standard' in IPR, workers conditions, environmental control, and trade in services is a manifestation of the U.S. new FTA. For instance, in IPR, the usual FTA requests members to abide by the 'TradeRelated Aspects of Intellectual Property Rights (TRIPS) agreement' as stipulated in the WTO, but the TPP sets a higher standard. The U.S. has a very strong competitive edge in technological innovation and knowledge economy. The high standard in IPR would help the U.S. in maintaining its superiority in this area and safeguarding its interests in technological transfer and patents trade. However, this might inhibit the least developed countries in acquiring technology at a low cost. The regulations on labor rights as well as environmental conditions are seen by Chinese analysts as a kind of pretexts used by the U.S. administration in imposing trade sanctions to least developed countries in the future. They would obstruct the exports of Chinese products. The principle of non-discrimination is adopted by the TPP in the regulations on government procurement. This is also regarded by Chinese analysts as a means to obstruct Chinese government's actions to buttress its state enterprises in order to support its crucial key industries (Wu and Qu, 2014, p. 71).

Though China would not suffer much from not joining the TPP in the short term, the TPP actually constrains the status and influence of China in fostering regional economic cooperation. Chinese economists believe that the accession of Japan to TPP while China is out of TPP would adversely affect the Chinese economy, as trade would then shift towards the twelve member states of TPP with tariffs for all commodities reduced to zero. However, for the sake of upgrading Chinese status and influence in East Asian economic cooperation, Beijing opts for ' $10+3$ ' in order to counter-balance the negative effects incurred upon China by the U.S.-dominated TPP, which is part of the American strategy of 'Rebalancing' and 'Pivot to Asia.' Beijing also thinks that the TPP complicates the great power relationship in the Asia-Pacific region, especially in China's bilateral relationship with Japan, ASEAN, Korea, and Russia, since the TPP would further reinforce the relationship between the U.S. and its military allies in the region.

It seems that China opts for an 'East Asian Strategy' rather than an 'AsiaPacific Strategy,' as the former yields more 'spillover' effects on the member countries. Among the strategic choices for China, the order for China's choices is in the following sequence: $10+1>$ ChinaJapan-Korea $>10+3>10+6($ RCEP $)>$ AsiaPacific Economic Cooperation (APEC) (Free Trade Area of the Asia-Pacific [FTAAP] $)>$ TPP $(\mathrm{Wu}$ and $\mathrm{Qu}, 2014$, p. 74). Meanwhile, the most important task for China is to establish an upgraded version of ACFTA, which means reduction of tariffs and trade barriers for sensitive products; enhancing Chinese investments in infrastructure, water and electricity, 
telecommunication, and raw materials; as well as promoting trade in services such as financial services and cooperation (Wei Min, 2015, p. 131). The next major task is to accelerate the negotiation of FTA for China-Japan-Korea, then $10+3$, and the negotiation of bilateral FTA with other regional powers such as Korea, Australia, Brunei, Malaysia, and Vietnam.

Both Japan and the U.S. have to sacrifice in order to demonstrate their goodwill for the establishment of TPP. The Japanese government has to make sacrifice regarding opening up their agricultural market. The self-sufficiency rate of agricultural products in Japan would be reduced from 40 per cent to 13 per cent, and, with the massive influx of foreign agricultural products, the agricultural population would probably be reduced by 3.5 million. The U.S. government has make sacrifice regarding its pharmaceutical industries, in which they have to shorten the length of their patents for new medicines from twelve years to eight years.

China was not invited to the negotiation on TPP, and it will not be able to fulfill some of the requirements in the near future. One requirement is obviously targeted against the Chinese state enterprises. The monopolization of key industries in China by the giant state enterprises, behind which is the state power, is against the 'spirit' of free trade according to the TPP. The regulations of TPP require that state enterprises should not enjoy any special privileges, so the key industries that are monopolized by the Chinese state enterprises, such as chemical engineering, steel, petroleum, energy, minerals, banking and finance, logistics, and telecommunication, would 'suffer' in the eyes of Chinese analysts. Another condition set by TPP is also targeted at
China, which are "new rules governing the free flow of data, privacy and cybersecurity ... and bans a swath of practices used by China and other countries to protect her local technology companies" (Donnan, 2015, p. 2). This is obviously set against the Chinese hackers stealing commercial and technological secrets from the U.S.

As a superpower, the U.S. still tries to safeguard its leadership position in deciding the so-called rules of the games (or international norms) in international trade and investments. If China wishes to enter the TPP, it has to make significant domestic reforms so as to abide by the new international norms. The TPP can thus be considered as a useful political instrument of Washington to foster fundamental changes within China. Nevertheless, it should be emphasized that higher standard on workers' rights and protection, better protection of IPR, and environmental conservation should be regarded as the major trends in economic globalization, and it is also in the interest of China to gradually implement a higher standard in these regards. Though it is clear that Washington wants to make use of TPP to stimulate China for further domestic reforms in order to fulfill the conditions laid down by the U.S. - just like what the U.S. did in the past in fostering domestic legal, financial, and economic reforms in China in order to become a member of WTO - it is imperative for China for its own sake to modify its economic structure and to upgrade its industries. So, the TPP setting a higher standard in many ways can be beneficial to China if the standard laid down will be conducive to further restructuring of Chinese economy. Interestingly, this argument is indeed echoed by Chinese economists ( $\mathrm{Wu}$ and Qu, 2014, p. 76). 
It seems that ASEAN is interested in signing bilateral FTA with regional powers by maximizing its own interests through the strategy of balancing in between the great powers. ASEAN has four members in the TPP. How the TPP is related to RCEP, FTAAP, and other bilateral FTAs and how they play a part in influencing regional economic integration remain to be studied. It is nevertheless certain that maneuvering in between the greatest powers in a skillful manner can render the maximum benefits for ASEAN. Establishing an FTA with China enables all the members of ASEAN to benefit from the vast Chinese market and attract Chinese investments, while the more prepared members are now opting for an upgraded FTA - the TPP - with the U.S. and Japan. This later can then help to counterbalance the possible over reliance on China from both the geopolitical and geo-economic perspectives.

\section{Conclusion}

As a Thai scholar has noted, "the problem for China ... is that its relationship with ASEAN lacks strategic trust due to lingering security concerns, while prospects for joint economic development are limited by ASEAN's fear of domination by its larger neighbor" (Parameswaran, 2013, p. 12). ASEAN "may worry that being overly dependent on China economically would allow Beijing to use its dominance to undermine their foreign policy autonomy" (Parameswaran, 2013, p. 11).

However, in the cases of Taiwan and Hong Kong, by 'yangli,' what the Chinese authorities wish to achieve is that 'rendered profits' will succeed in winning the hearts of people, that is, economic integration will lead to political integration. In reality, the Chinese practice, or malpractice, does not succeed in winning the hearts of the people in Taiwan or Hong Kong; rather, the contrary is true. The massive inflow of Chinese capital might modify the economic landscape and structure, fostering the dominating position of the Chinese capital. If the Chinese capital dominates, political domination is a natural corollary. This is the basic reason why the Taiwan students fought against the Cross-Strait Service Trade Agreement in the spring of 2014.

It is true that between China and its neighbors, economic interdependence is the growing trend that is inevitable. However, if the interdependence is 'asymmetric' - meaning that one side benefits more than its counterpart, the partner country will be skeptical of the real intention of the bigger power, resulting in the loss of political trust. The reason why China is interested in dealing with its neighbors on a bilateral basis perhaps is due to the underlying logic of 'asymmetry.' So, Beijing should be aware of the national sentiments of ASEAN countries regarding their fear of domination and be cautious of any economic endeavors given the possible political and social implications.

\section{About the Author}

Ting Wai is a professor at the Department of Government and International Studies at Hong Kong Baptist University. He graduated from the Chinese University of Hong Kong and obtained his Ph.D. in Political Science and International Relations from the University of Paris-X (Nanterre), France. He was also former president of The Hong Kong Association for European Studies from 2006 to 2017. 


\section{Reference}

ASEAN Secretariat. (2007). ASEAN Economic Community Blueprint. Retrieved from http://asean.org/wpcontent/uploads/archive/5187-10.pdf

ASEAN-China Center. (2010). ASEAN and China. Retrieved from http://www.asean-chinacenter.org/english/201006/23/c_13365143_2.htm

ASEAN Secretariat. (2015). Top Ten Sources of Foreign Direct Investment Inflows in ASEAN. In ASEAN Foreign Direct Investment Statistics Database. Retrieved from http://www.asean.org/images/2015/Ju ne/FDI_tables/Table\%2027.pdf

ASEAN Secretariat. (2015). Top Ten ASEAN Trade Partner Countries/Regions, 2014. In ASEAN External Trade Statistics. Retrieved from

http://www.asean.org/images/2015/Jul y/external_trade_statistic/table20_as of 17June15.pdf

Chinvanno, A. (2015). ASEAN-China Relations: Prospects and Challenges. RJSH, 2(1) (Jan-Jun).

Donnan, S. (2015). Trade Deal Takes Aim at Chinese Hacking. Financial Times, 5 Nov.

Fan, Ying. (2012). What can ACFTA Share with FTAAP? In Flick, K. E., \& Kemburi, K. M. (Eds.). ASEAN-China Free Trade Area: Challenges, Opportunities and the Road Ahead. RSIS Monograph (22), S. Rajaratnam School of International Studies, Nanyang Technological University.

Goh, E. (2007-08). Great Powers and Hierarchical Order in Southeast Asia:
Analysing Regional Security Strategies. International Security, 32(3) (Winter), 113-157.

Gu, G. (2013). The defects of 'On the Threat from Chinese Soft Power': the Case of Southeast Asia. Dongnanya Yanjiu (Southeast Asian Studies), 4, 3240.

Hatakeyama, N. (2012). ACFTA in the Context of Asia-Pacific Economic Relations. in Flick, K. E., \& Kemburi, K. M. (Eds.). ASEAN-China Free Trade Area: Challenges, Opportunities and the Road Ahead. RSIS Monograph (22), S. Rajaratnam School of International Studies, Nanyang Technological University.

International Monetary Fund. (2015). China: Exports and Imports. In Direction of Trade Statistics. International Monetary Fund.

Keohane, R. O., \& Nye, J. S. (2001). Power and Interdependence ( $3^{\text {rd }}$ ed.). New York: Longman.

Jialin, J., \& Li, C. (2013). Analysis of Trade Development between China and Association of Southeast Asian Nations. Journal of Behavioural Economics, Finance, Entrepreneurship, Accounting and Transport, 1(1), 15-20.

Jiansheng, W., \& Fengjie, Q. (2014). TPP: Trends, Influence and Strategic Policy Reactions. Guoji Jingji Pinglun (Review of International Economics), 1.

Parameswaran, P. (2013). Beijing Unveils New Strategy for ASEAN-China Relations. In China Brief, The Jamestown Foundation, 13(21).

Min, W. (2015). Constructing the 'Upgraded Version' of China-ASEAN Free Trade Area: Problems and 
Perspectives. Guoji Wenti Yanjiu (International Studies), 2, 127-140.

Ministry of Commerce, People's Republic of China. (2013). Premier Li Keqiang's keynote speech at 10th China-ASEAN Expo. Retrieved from http://english.mofcom.gov.cn/article/zt _10thchina/column1/201309/201309002 87593.shtml

Soerakoesoemah, R. (2012). ASEAN-China Free Trade Area. in Flick, K. E., \& Kemburi, K. M. (Eds.). ASEAN-China Free Trade Area: Challenges, Opportunities and the Road Ahead. RSIS Monograph (22), S. Rajaratnam School of International Studies, Nanyang Technological University.

Salidjanova, N., Koch-Weser, I., \& Klanderman, J. (2015). China's
Economic Ties with ASEAN: a Countryby-Country Analysis. Staff Research Report, U.S.-China Economic and Security Review Commission.

Trading Economics. (n.d.). China Foreign Exchange Reserves. Retrieved from http://www.tradingeconomic.com/chi na/foreign-currency-reserves

Xiaoke, W., \& Huizhi, Z. (2015). Great Power Competitions and China's Economic Diplomacy Towards Southeast Asia. Dongnanya Yanjiu (Southeast Asian Studies), 1, 27-32.

Xiaoqin, Z. (2015). The Operational Performance of the China-ASEAN Free Trade Area and Its Sustainable Development Path. Xiandai Guoji Guanxi, (Contemporary International Relations), 7. 